\title{
Ultrastructural Analysis of the Surface Changes on the Nickel-Titanium Endodontic Instruments after Multiple Use
}

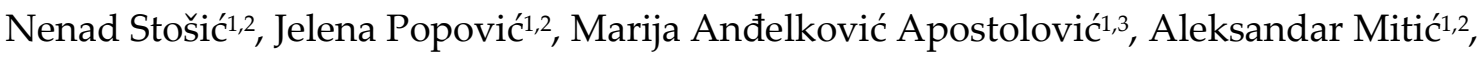 \\ Marija Nikolić1,2, Radomir Barac ${ }^{1,2}$ \\ ${ }^{1}$ University of Niš, Faculty of Medicine, Niš, Serbia \\ ${ }^{2}$ Clinic of Dentistry, Department of Restorative Dentistry and Endodontics, Niš, Serbia \\ ${ }^{3}$ Medical Statistics and Informatics, Public Health Institute, Niš, Serbia
}

SUMMARY

One of the primary goals in endodontics is efficient cleaning and shaping of the root canal while maintaining its original configuration. Numerous studies highlight the advantage of using nickel-titanium instruments and the most important is their high flexibility and the ability to penetrate the curved canals. The aim of this study was to analyze the ultrastructure of the surface of nickel-titanium endodontic files before and after use. Eighty-four instruments were included in this study. The instruments were used one, three and six times for root canal preparation on extracted upper premolars. The analysis was performed based on the number of uses and the size of the instruments. Changes on flat surfaces in the grooves of the instruments, defects of the cutting edges and fractures were evaluated. The surface ultrastructure was analyzed on a scanning electron microscope (SEM). SEM analysis showed irregularities on the surfaces of the new instruments. Surface defects and damage of the cutting edges were present after the first use. After three uses, the damage was more evident in instruments of all sizes. After six uses, all instruments showed damage of the cutting edges, and a significant number of fractures were observed. Irregularities on the working parts are already noticed on the new endodontic instruments and originate from the production process. The first signs of damage appear after the first use. In order to prevent errors in clinical work during root canal preparation, it is recommended that the number of instruments uses should be limited.

Key words: endodontic instruments, nickel-titanium, damages, SEM

Corresponding author:

Nenad Stošić

e-mail: nenadstosic10@gmail.com 


\section{INTRODUCTION}

Endodontic treatment of uninfected and infected root canal system includes its cleaning, shaping, disinfection and obturation (1). Although successful endodontic therapy depends on several factors, one of the most important steps in endodontic treatment is the biomechanical preparation of the root canal while maintaining its original configuration (2). The biomechanical instrumentation is important for the removal of the organic and inorganic debris, as well as for providing the correct placement of the obturation material into the root canal system (3). However, when preparing curved canals, standard stainless steel instruments are usually not successful in preserving their original shape (4). Numerous studies emphasize the advantage of nickeltitanium (NiTi) instruments, where the most important is their high flexibility and the possibility of penetration into the most curved canals $(5,6)$. Clinical concern is that they undergo fatigue failure which occurs unexpectedly (7). During their use, the cutting edges wear due to friction with the root canal walls. Simultaneous use of chemical agents for root canal irrigation or contact with cleaning and disinfection agents, as well as sterilization, have an impact on the occurrence of material fatigue and corrosion of instruments. All these factors contribute to degradation and deterioration of NiTi instruments, which can lead to their fracture (8).

\section{AIM}

The aim of this study was to analyze the ultrastructure of the surface of NiTi endodontic instruments before and after multiple use.

\section{MATERIAL AND METHODS}

The study included 14 sets of NiTi hand files (Dentsply, Maillefer, Ballaigues, Switzerland) size 15 to 40. After taking from the manufacturer's packaging, the instruments were cleaned of manufacturing impurities in an ultrasonic cleaner (JUSS01, JEOL) with distilled water for 15 minutes at a frequency of $28 \mathrm{kHz}$. The instruments of each set were exposed to one, three and six root canal instrumentations in simulated clinical conditions on extracted upper premolars. Four sets were subjected to one use, four were used three times, four sets six times, and two were not used and served as a con- trol. After the preparation of the access cavity, the preparation of each root canal was performed using one set of instruments (15 - 40) and applying "stepback" technique with $0,5 \%$ sodium hypochlorite irrigation. Preparations of all root canals were performed by one researcher to avoid interpersonal errors. After each use, the instruments were subjected to cleaning and sterilization procedures that included soaking in 3\% hydrogen peroxide, manual brushing, ultrasonic cleaning, and autoclave sterilization. The samples were then prepared for scanning electron microscopic examination (SEM) (1, $3,7)$

In order to obtain adequate visualization of the working parts of the instruments, the handles of the instruments were cut off, and their working parts were fixed to the cylindrical supports with a fixing agent (Dotite paint xc 12 Carbon JEOL, Tokyo, Japan) and sputter coated with gold/palladium (in the unit JFC 110 Ion Sputter JEOL). The surface of the instruments was observed and analyzed on a scanning electron microscope type JEOL JSM 5300.

Due to the assumption that different sizes of the instruments are differently susceptible to damage, the samples were divided into three groups: I group - small size (sizes 15 and 20); II group medium size (sizes 25 and 30); III group - large size (sizes 35 and 40). The analysis of the ultrastructure of working parts was performed in relation to the number of uses and in relation to the size of the instruments (Table 1).

Table 1. Analyzed endodontic instruments in relation to the number of uses and their size

\begin{tabular}{c|c|c|c|c|c}
\hline \hline & Control & $\mathbf{1}$ use & $\mathbf{3}$ uses & $\mathbf{6}$ uses & Total \\
\hline I group & 4 & 8 & 8 & 8 & 28 \\
\hline II group & 4 & 8 & 8 & 8 & 28 \\
\hline III group & 4 & 8 & 8 & 8 & 28 \\
\hline Total & 12 & 24 & 24 & 24 & 84 \\
\hline \hline
\end{tabular}

The following ultrastructural changes on the instruments were analyzed:

1. Changes on the flat surfaces of the thread between the two blades (surface irregularities, the appearance of metal particles due to poor finishing and accumulation of debris);

2. Defects of the cutting edges (blunting and refraction);

3. Instrument fractures 
Due to the superelasticity of the alloy, deformations (bending and distortion) were not expected and were not analyzed in this study.

The research was performed at the Department of Restorative Dentistry and Endodontics, Clinic of Dentistry and the Institute for Biomedical Research, Faculty of Medicine, University of Niš.

Statistical analysis was performed using $\chi^{2}$ and Fisher Exact test. A p value less than 0.05 was considered to be statistically significant.

\section{RESULTS}

Ultrastructural analysis of the control group revealed surface irregularities in the grooves between cutting edges in $33.3 \%$ of instruments (Figure $1)$. After one use, there was no change in the ultra- structure of the surface compared to the control group. Surface irregularities were observed in $8.3 \%$ of small, $8.3 \%$ medium and $16.7 \%$ of large instruments. After three uses, $41 \%$ of instruments had surface damages (8.3\% small, $12.5 \%$ medium and $20.8 \%$ large), while after six uses, $62.5 \%$ of instru-ments showed irregularities of the surface structure $(12.5 \%$ small, $25 \%$ medium and $25 \%$ large). The analysis showed that surface damages were increased with the number of uses, but the difference was not statistically significant $\left(\chi^{2}=4.363 ; \mathrm{p}=0.122\right)$ (Table 2$)$.

Ultrastructural analysis also showed defects of the cutting edges in $33.3 \%$ of control samples (Figure 1). After one use, there was an increase in the number of damaged samples, especially in the group of medium instruments (12.5\%). After three uses, the tested instruments had damaged cutting edges $(12.5 \%$

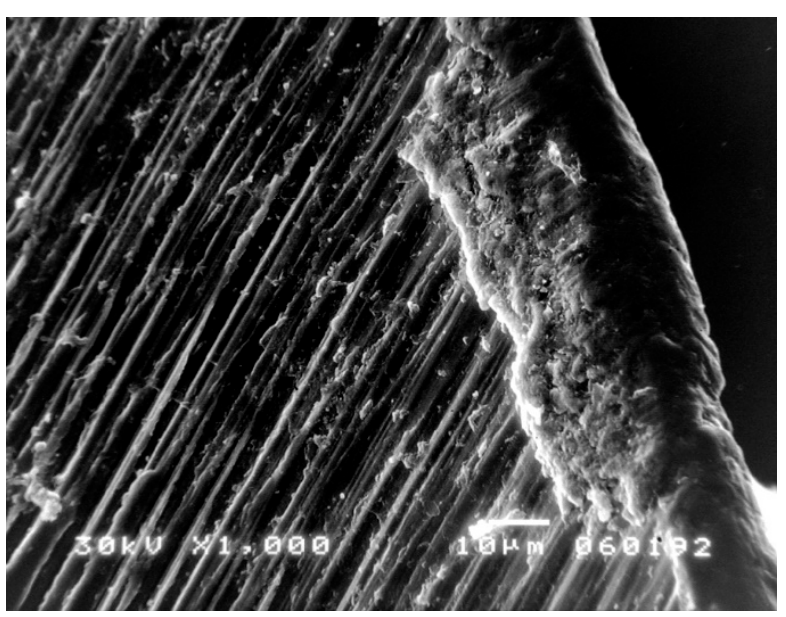

Figure 1. SEM of the blunt cutting edge and surface irregularities of the new NiTi endodontic instrument

Table 2. Surface irregularities on NiTi instruments before and after use

\begin{tabular}{c|c|c|c|c|c|c|c|c}
\hline \hline \multirow{2}{*}{$\begin{array}{c}\text { Surface } \\
\text { irregularities }\end{array}$} & \multicolumn{9}{|c|}{ Number of uses } & \multicolumn{2}{c}{ 6 N (\%) } \\
\cline { 2 - 9 } & \multicolumn{2}{|c|}{ Control N (\%) } & \multicolumn{2}{|c|}{$\mathbf{1 ~ N ~ ( \% )}$} & \multicolumn{2}{c}{ 3 Not } \\
\hline $\begin{array}{c}\text { Size of the } \\
\text { instruments }\end{array}$ & Damaged & $\begin{array}{c}\text { Not } \\
\text { damaged }\end{array}$ & Damaged & $\begin{array}{c}\text { Not } \\
\text { damaged }\end{array}$ & Damaged & $\begin{array}{c}\text { Not } \\
\text { damaged }\end{array}$ & Damaged & $\begin{array}{c}\text { Not } \\
\text { damaged }\end{array}$ \\
\hline I group $^{\mathrm{a}}$ & $1(8,3)$ & $3(25)$ & $2(8,3)$ & $6(25)$ & $2(8,3)$ & $6(25)$ & $3(12,5)$ & $5(20,8)$ \\
\hline II group $^{\mathrm{b}}$ & $1(8,3)$ & $3(25)$ & $2(8,3)$ & $6(25)$ & $3(12,5)$ & $5(20,8)$ & $6(25)$ & $2(8,3)$ \\
\hline III group $^{c}$ & $2(16,7)$ & $2(16,7)$ & $4(16,7)$ & $4(16,7)$ & $5(20,8)$ & $3(12,5)$ & $6(25)$ & $2(8,3)$ \\
\hline Total $^{\mathrm{d}}$ & $4(33,3)$ & $8(66,7)$ & $8(33,3)$ & $16(66,7)$ & $10(41,7)$ & $14(58,3)$ & $15(62,5)$ & $9(37,5)$ \\
\hline \hline
\end{tabular}

$\mathrm{a} \chi^{2}=0,403 ; \mathrm{p}=0,817$

$\mathrm{b} \chi^{2}=4,363 ; \mathrm{p}=0,112$

$c \chi^{2}=1,066 ; p=0,586$

$\mathrm{d} \chi^{2}=4,363 ; \mathrm{p}=0,112$ 


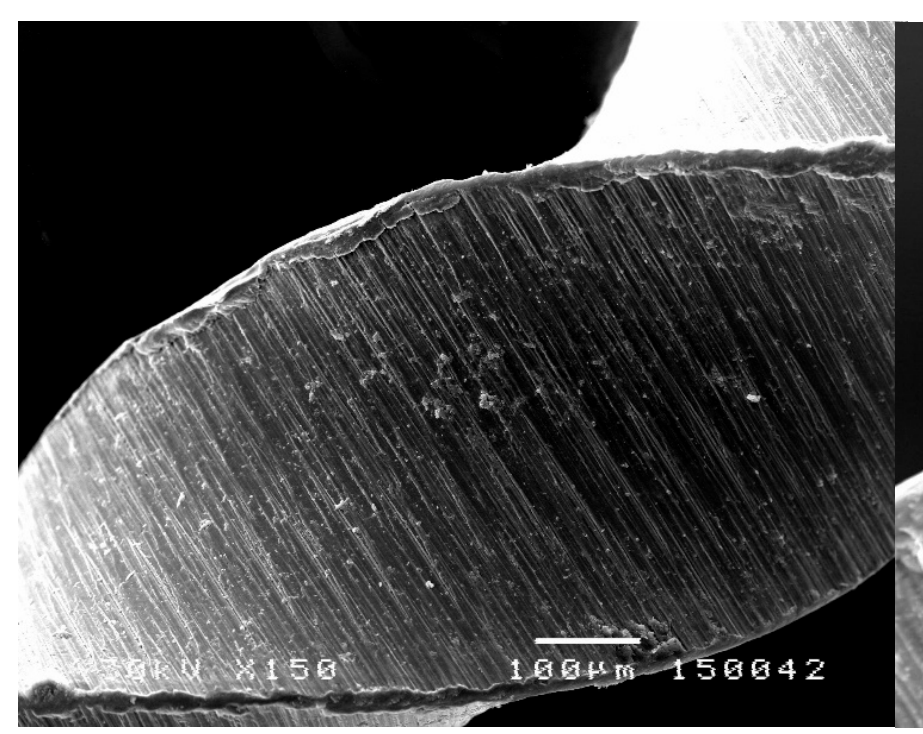

Figure 2. SEM of the disrupted cutting edge and metal surface irregularities with adhered dentin debris

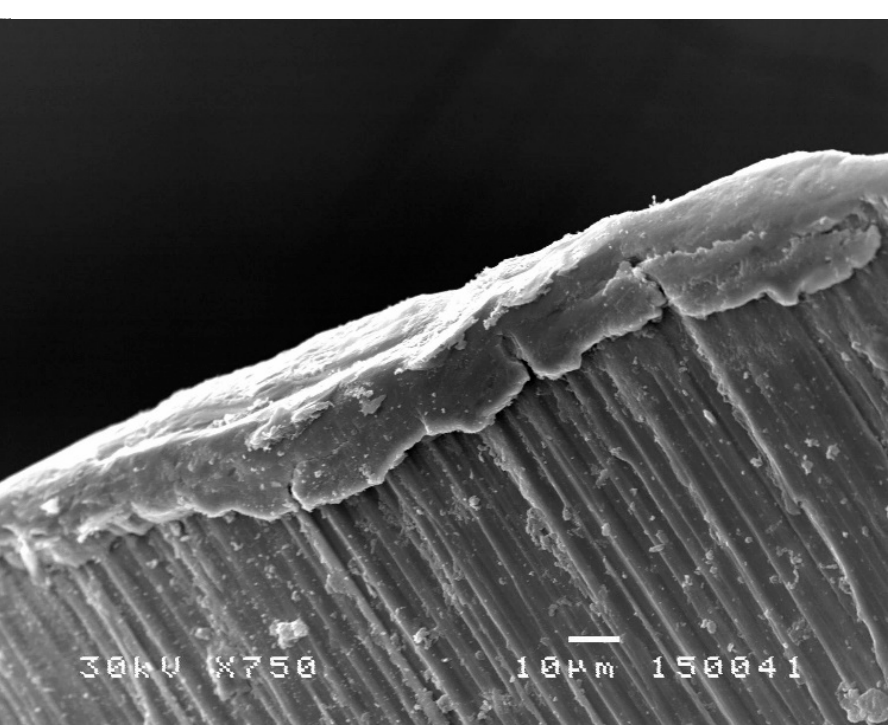

Figure 3. SEM of the damaged cutting edge on a NiTi endodontic instrument

Table 3. Defects of the cutting edges on the working parts of NiTi instruments before and after use

\begin{tabular}{|c|c|c|c|c|c|c|c|c|}
\hline \multirow{3}{*}{$\begin{array}{c}\begin{array}{c}\text { Defects of } \\
\text { cutting } \\
\text { edges }\end{array} \\
\text { Size of the } \\
\text { instruments }\end{array}$} & \multicolumn{8}{|c|}{ Number of uses } \\
\hline & \multicolumn{2}{|c|}{ Control N (\%) } & \multicolumn{2}{|c|}{$1 \mathrm{~N}(\%)$} & \multicolumn{2}{|c|}{$3 \mathrm{~N}(\%)$} & \multicolumn{2}{|c|}{$6 \mathrm{~N}(\%)$} \\
\hline & Damaged & $\begin{array}{c}\text { Not } \\
\text { damaged }\end{array}$ & Damaged & $\begin{array}{c}\text { Not } \\
\text { damaged }\end{array}$ & Damaged & $\begin{array}{c}\text { Not } \\
\text { damaged }\end{array}$ & Damaged & $\begin{array}{c}\text { Not } \\
\text { damaged }\end{array}$ \\
\hline I group $^{a}$ & $1(8,3)$ & $3(25)$ & $1(4,2)$ & $7(29,2)$ & $3(12,5)$ & $5(20,8)$ & $8(33,3)$ & $0(0)$ \\
\hline II group g $^{b}$ & $1(8,3)$ & $3(25)$ & $3(12,5)$ & $5(20,8)$ & $5(20,8)$ & $3(12,5)$ & $8(33,3)$ & $0(0)$ \\
\hline III group ${ }^{c}$ & $2(16,7)$ & $2(16,7)$ & $2(8,3)$ & $6(25)$ & $4(16,7)$ & $4(16,7)$ & $8(33,3)$ & $0(0)$ \\
\hline Total $^{\mathrm{d}}$ & $4(33,3)$ & $8(66,7)$ & $6(25)$ & $18(75)$ & $12(50)$ & $12(50)$ & $24(100)$ & $0(0)$ \\
\hline $\begin{array}{l}{ }^{\mathrm{a}} \mathrm{p}=0,002 \\
{ }^{\mathrm{b}} \mathrm{p}=0,039 \\
\mathrm{c} p=0,013 \\
{ }^{\mathrm{d}} \chi^{2}=28.8 ; \mathrm{p}<0\end{array}$ & & & & & & & & \\
\hline
\end{tabular}

Table 4. Fractures of NiTi instruments after multiple use

\begin{tabular}{c|c|c|c|c|c|c|c|c}
\hline \hline \multirow{2}{*}{ Fractures } & \multicolumn{7}{|c}{ Number of uses } \\
\cline { 2 - 9 } & \multicolumn{2}{|c|}{ Control N (\%) } & \multicolumn{2}{|c|}{$\mathbf{1 ~ N ~ ( \% )}$} & \multicolumn{2}{|c}{$\mathbf{3 ~ N ~ ( \% )}$} & \multicolumn{2}{c}{$\mathbf{6 ~ N ~ ( \% ) ~}$} \\
\hline $\begin{array}{c}\text { Size of the } \\
\text { instruments }\end{array}$ & Damaged & $\begin{array}{c}\text { Not } \\
\text { damaged }\end{array}$ & Damaged & $\begin{array}{c}\text { Not } \\
\text { damaged }\end{array}$ & Damaged & $\begin{array}{c}\text { Not } \\
\text { damaged }\end{array}$ & Damaged & $\begin{array}{c}\text { Not } \\
\text { damaged }\end{array}$ \\
\hline I group & $0(0)$ & $8(33,3)$ & $0(0)$ & $8(33,3)$ & $0(0)$ & $8(33,3)$ & $0(0)$ & $8(33,3)$ \\
\hline II group & $0(0)$ & $8(33,3)$ & $0(0)$ & $8(33,3)$ & $0(0)$ & $8(33,3)$ & $5(20,8)$ & $3(12,5)$ \\
\hline III group & $0(0)$ & $8(33,3)$ & $0(0)$ & $8(33,3)$ & $0(0)$ & $8(33,3)$ & $3(12,5)$ & $5(20,8)$ \\
\hline Total & $0(0)$ & $12(100)$ & $0(0)$ & $24(100)$ & $0(0)$ & $24(100)$ & $8(33,3)$ & $16(66,7)$ \\
\hline \hline
\end{tabular}


small, 20.8\% medium and 16.7\% large) (Figure 2), while after six uses, the defects of the cutting edges were observed in $100 \%$ of the tested instruments (Figure 3). The analysis determined the existence of a statistically significant difference in cutting edge damage depending on the number of uses for the whole examined group $\left(\chi^{2}=28.8 ; p<0.001\right)$, as well as in relation to the size of the instruments: I ( $p=$ 0.002), II ( $\mathrm{p}=0.039)$ III $(\mathrm{p}=0.013)$ (Table 3).

Table 4 shows the distribution of fracture occurrence after a repeated use of NiTi endodontic instruments. The first fracture occurred after the fourth use, while after the sixth use, a total of 33.3\% of the instruments were fractured $(20.8 \%$ medium and $12.5 \%$ large).

\section{DISCUSSION}

One of the primary goals of endodontic treatment is the removal of the existing and potential irritants from the root canal system, which is achieved by chemomechanical cleaning and shaping (8). The production characteristics and design of the instruments are essential for efficient preparation. Stainless steel instruments have good cutting efficiency, however, their modulus of elasticity is high which makes them less flexible (4).

In order to overcome the disadvantages of stainless steel instruments, NiTi instruments were introduced in dentistry in 1988 to take advantage of their physical and mechanical properties (9). The superelasticity of the NiTi alloy makes these instruments suitable for processing narrow and curved canals (10). However, despite their high flexibility, their fractures are possible and most often occur due to torsional stress and flexural fatigue. Torsional fractures occur when a part of the instrument, and most often the tip, is locked in the canal, while the operator continues with rotation, then the elastic limit of the metal is exceeded by the torque exerted by handpiece, so the fracture of the instrument becomes inevitable. Fractures caused by flexural fatigue occur due to fatigue of the metal of which the instrument was made after repeated uses (11). For this reason, the number of uses of endodontic instruments must be limited. It is a known fact that endodontic instruments are discarded in everyday practice only when they are visibly deformed or broken. Numerous authors have examined the influence of multiple use on the torsional and flexion properties of endodontic instruments $(9,12)$.
The authors agree that the torsional strength of the used instruments is lower compared to the new instruments. The great concern in clinical use is related to unexpected failure during work as this instruments can undergo fracture without any signs of visible defects or previous permanent deformation (13). Although they are not visible to the naked eye after clinical use, numerous damage occurs at the microscopic level $(7,9,14)$. Since the visual inspection would not seem to be an ideal way of evaluating NiTi instruments in order to prevent the fracture, this study was performed to analyse defects on the working parts of the instruments at the microscopic level after a certain number of uses. Numerous literature data show that scanning electron microscopy (SEM) is a reliable method for the analysis of ultrastructural changes on new and used endodontic instruments $(1,3,7,9,10,14)$.

The results of this research confirmed that certain defects can already be noticed on the new instruments, where the most common were the appearance of irregularities of the metal surface and blunted cutting edges. Since such defects originate from the manufacturing process, they are not related to the size of the instruments. The occurrence of such defects can compromise the cutting efficiency of endodontic instruments, promote fatigue of the material with consequential fracture and potentially cause problems with corrosion (15).

The surface irregularities were present in instruments of all sizes and were not significantly changed with the number of uses of the instruments, but since they represent a retention surface, after multiple use dentin debris was retained on their surface. Debris retention and instrument wear were examined in the study by Emsallati et al. (8) and proved that in the presence of surface irregularities, significant amounts of debris stay retained on the surface of the instruments even after ultrasonic cleaning.

The number of instruments with cutting edge defects has risen with the number of uses. Blunt cutting edges were also observed in new instruments, but their number has significantly increased with the number of uses; defects of cutting edges were observed after six uses in all instruments. Instrument deformations like thread distortion and derotation did not occur due to the superelasticity of the alloy, while the first instrument fractures occurred after the fourth use. Similar results were obtained in the study by Bonetti-Filho et al. (16) and 
recommended that small size instruments should be discarded after the first use. Although many manufacturers label their NiTi files as single use devices, most of practices indicate that NiTi instruments are reused. This trend is most likely a result of the price of NiTi files. According to Logsdon et al. (17), 74\% respondents in their study reuse NiTi instruments, and the largest proportion of practitioners (40.5\%) discard them after the third use.

Sterilization can also have a significant effect on instruments. Multiple autoclave sterilization can also modify surface topography and chemical composition of NiTi instruments (18). Literature data revealed that the pre-sterilization cleaning in sodium hypochlorite, followed by sterilization, showed a significant corrosion rate of the endodontic instruments compared to the control group (19). These re- sults are significant because corrosion is one of the first factors that promote fatigue of the material from which endodontic instruments are made and then become more susceptible to damage with multiple use.

\section{CONCLUSION}

New nickel-titanium endodontic instruments have numerous defects on their surface that originate from the manufacturing process. The first signs of damage on the instruments appear after the first clinical use. In order to prevent errors in clinical work during root canal preparation, it is recommended that the number of instruments uses should be limited.

\section{References}

1. Chianello G, Specian VL, Hardt LCFet al. Surface finishing of unused rotary endodontic instruments: A SEM study. Braz Dent J 2008; 19: 109-13. https://doi.org/10.1590/S0103-64402008000200004

2. Peters OA. Current challenges and concepts in the preparation of root canal systems. J Endodont 2004; 30: 559-67. https://doi.org/10.1097/01.DON.0000129039.59003.9D

3. Orhan EO, Ertugrul IF. Cyclic fatigue life of novel rotary compactors: A scanning electron microscopy evaluation. Microsc Res Tech 2020; 83: 66-71. https://doi.org/10.1002/jemt.23389

4. Zuolo MI, Walton RE. Instrument deterioration with usage: nickel titaniun versus stainless steel. Quintessence Int 1997; 28: 397-402. PMID: 9477904

5. Guelzow A, Stamm O, Martus P, Kielbassa AM. Comparative study of six rotary nickel-titanium systems and hand instrumentation for root canal preparation. Int Endod J 2005; 38: 743-52. https://doi.org/10.1111/j.1365-2591.2005.01010.x

6. Hulsmann M, Donnermeyer D, Schafer E. A critical appraisal of studies on cyclic fatigue resistance of engine-driven endodontic instruments. Int Endod J 2019, 52: 1427-45. https://doi.org/10.1111/iej.13182

7. Pallavi Reddy Y, Kavita S, SubbaRao CV. Cyclic fatigue testing of three different rotary nickel titanium endodontic instruments in simulated curved canals-an in vitro SEM analysis. J Clin Diagnostic Res 2014; 8: 211-3.

https://doi.org/10.7860/JCDR/2014/7569.4062

8. Elmsallati EA, Wadachi R, Ebrahim AK, Suda H. Debris retention and wear in three different nickel-titanium rotary instruments. Aust Endod J 2006; 32: 107-11. 
https://doi.org/10.1111/j.1747-4477.2006.00029.x

9. Yamazaki-Arasaki AK, Cabrales RJS, Kleine BMet al. Qualitative analysis of files of four different rotary systems, before and after being used for the twelth time. Microcs Res Techniq 2013; 76: 79-85. https://doi.org/10.1002/jemt.21021

10. Alapati SA, Brantley WA, Svec TAet al. Scanning electron microscope observations of new and used nickel-titanium rotary files. J Endodont 2003; 29: 667-9.

https://doi.org/10.1097/00004770-200310000-00014

11. Plotino G, Grande NM, Cordaro Met al. A review of cyclic fatigue testing of nickel-titanium rotary instruments. J Endodont 2009; 35: 1469-76. https://doi.org/10.1016/j.joen.2009.06.015

12. Vieira EP, Nakagawa RKL, Buono VTL, Bahia MGA. Torsional behavior of rotary NiTi ProTaper instruments after multiple clinical use. Int Endod J 2009; 42: 947-53.

https://doi.org/10.1111/j.1365-2591.2009.01602.x

13. Fišerová E, Chvosteková M, Bjlašková $S$, Bumbálek M, Zdenjk J. Survival analysis of factors influencing cyclic fatigue of nickel-titanium endodontic instruments. Adv Mater Sci Eng 2015, Article ID 189703, 6 pages. https://doi.org/10.1155/2015/189703
14. Luzi A, Forner L, Almenar A, Llena C. Microstructure alterations of rotary files after multiple simulated operative procedures. Med Oral Patol Oral Cir Bucal 2010; 15: 658-62. https://doi.org/10.4317/medoral.15.e658

15. Thompson SA. An overview of nickel-titanium alloys used in dentistry. Int Endod J 2000; 43: 69-76. https://doi.org/10.1046/j.1365-2591.2000.00339.x

16. Bonetti-Filho I, Esberard R, Leonardo RT, Del Rio CE. Microscopic evaluation of three endodontic files pre and post instrumentation. J Endodont 1998; 24: 461-3.

https://doi.org/10.1016/S0099-2399(98)80046-0

17. Logsdon J, Dunlap C, Arias Aet al. Current trends in use and reuse of nickel-titanium engine-driven instruments: A survey of endodontists in the United States. J Endodont 2020; 46, 391-6. https://doi.org/10.1016/j.joen.2019.12.011

18. Spagnuolo G, Ametrano G, D'Anto Vet al. Effect of autoclaving on the surfaces of TiN -coated and conventional nickel-titanium rotary instruments. Int Endod J 2012; 45:1148-55.

https://doi.org/10.1111/j.1365-2591.2012.02088.x

19. Casella G, Rosalbino F. Corrosion behaviour of NiTi endodontic instruments. Corros Eng Sci Techn 2011; 46: 521-3. https://doi.org/10.1179/147842209X12559428167445 


\title{
Ultrastrukturna analiza površinskih promena na endodontskim instrumentima od nikl-titanijuma nakon višestruke upotrebe
}

\author{
Nenad Stošić1,2, Jelena Popović1,2, Marija Anđelković Apostolović1,3, Aleksandar Mitić1,2, \\ Marija Nikolić'1,2, Radomir Barac ${ }^{1,2}$ \\ ${ }^{1}$ Univerzitet u Nišu, Medicinski fakultet, Niš, Srbija \\ ${ }^{2}$ Klinika za stomatologiju, Departman za restorationu stomatologiju i endodonciju, Niš, Srbija \\ ${ }^{3}$ Medicinska statistika i informatika, Institut za javno zdravlje Niš, Niš, Srbija
}

\section{SAŽETAK}

Jedan od primarnih ciljeva preparacije kanalnog sistema je efikasno čišćenje i oblikovanje kanala korena zuba uz održavanje njegove originalne konfiguracije. Brojne studije ističu prednost korišćenja instrumenata od nikl-titanijuma zbog niza prednosti, od kojih su najvažnije njihova visoka fleksibilnost i mogućnost prodora u najzakrivljenije kanale. Cilj studije bio je da se izvrši ultrastrukturna analiza površine ručnih endodontskih turpija od nikl-titanijuma pre i posle njihove upotrebe. Osamdeset četiri instrumenta bilo je uključeno u ovu studiju. Instrumenti su podeljeni u grupe i korišćeni jedanput, tri i šest puta, za preparaciju kanala korena zuba na ekstrahiranim gornjim premolarima. Analiza je izvršena na osnovu broja upotreba i veličine instrumenata. Analizirane su promene na ravnim površinama u žlebovima instrumenata, promene na sečivima $\mathbf{i}$ frakture. Ultrastruktura površine radnih delova instrumenata analizirana je na skening elektronskom mikroskopu (SEM). SEM analiza pokazala je nepravilnosti na površinama novih instrumenata. Defekti površine i oštećenja sečivnih ivica su bili prisutni već posle prve upotrebe. Nakon tri upotrebe, oštećenja su bila evidentnija i javljala su se kod većeg broja instrumenata svih veličina, a registrovane su i prve frakture. Nakon šest upotreba, svi instrumenti pokazali su oštećenje sečivnih ivica, a uočen je i značajan broj fraktura. Nepravilnosti na radnim delovima zapažaju se već na novim endodontskim instrumentima i vode poreklo iz procesa proizvodnje. Prvi znaci oštećenja javljaju se već posle prve upotrebe. Da bi se sprečile greške u kliničkom radu tokom preparacije kanala korena, preporuka je da broj upotreba endodontskih instrumenata bude ograničen.

Ključne reči: endodontski instrumenti, nikl-titanijum, oštećenja, SEM 